\title{
Antibodies against human influenza viruses in Galliformes order
}

\author{
Behnaz Heydarchi ${ }^{12^{*}}$, Masoumeh Tavassoti Kheiri ${ }^{1}$, Seyed Masoud Hosseini ${ }^{2}$, Nariman Sheykhi ${ }^{3}$, \\ Seyedeh Fahime Mousavi ${ }^{2}$, Reza Khaltabadi Farahani ${ }^{2}$, Rouzbeh Bashar ${ }^{1}$ \\ From Institut Pasteur International Network Annual Scientific Meeting \\ Hong Kong. 22-23 November 2010
}

Influenza A virus is always concerned as an infectious agent in birds and other mammalian such as humans. Although it is believed that barriers among various species restrict the transmission of influenza viruses, there are evidences implying that origin of all human influenza viruses is derived from avian influenza viruses. To determine the prevalence of human $\mathrm{H} 1$ and $\mathrm{H} 3$ viruses in the captive birds of Galliformes order, a serological surveillance was carried in Tehran Zoo, Saiee Park and Pardisan Park of Tehran, from November 2008 to February 2009. Sera samples were collected from 7 species including Chickens, Guinea fowls, Partridges, Pheasants, Turkeys and Quails and presence of antibodies was detected by haemagglutination inhibition assay. Sera of chickens immunized by human influenza vaccine were used as positive control in the assays. In total, $84.61 \%$ and $100 \%$ of sera samples had antibodies against human influenza $\mathrm{H} 1$ and H3 viruses, respectively. The Geometric Mean Titer (GMT) value for $\mathrm{H} 1$ antibodies was 30.33 whereas that related for $\mathrm{H} 3$ antibodies was 57.36 . Significantly the highest GMT value and the greatest antibody titers were observed in chicken species. As HI assay is able to detect haemagglutination antibodies as soon as 2 weeks to 1 year post-infection, the results of this study indicate that seropositive captive birds were infected during recent year with $\mathrm{H} 1$ and $\mathrm{H} 3$ virus strain, closely related to human strains. Moreover, as the peak of influenza epidemic in human population in Tehran was at the same time with our sample collection, it could be concluded that influenza viruses' transmission between human and captive birds occurred.

'Influenza Unit, Pasteur Institute of Iran, Tehran, Iran

Full list of author information is available at the end of the article
Author details

${ }^{1}$ Influenza Unit, Pasteur Institute of Iran, Tehran, Iran. ${ }^{2}$ Department of Microbiology, Faculty of Biological Sciences, Shahid-Beheshti University, Tehran, Iran. ${ }^{3}$ Department of Clinical Sciences, Faculty of Specialized Veterinary Science, Science and Research Campus, Islamic Azad University, Tehran, Iran.

Published: 10 January 2011

doi:10.1186/1753-6561-5-S1-P3

Cite this article as: Heydarchi et al:: Antibodies against human influenza viruses in Galliformes order. BMC Proceedings 2011 5(Suppl 1):P3.

Submit your next manuscript to BioMed Central and take full advantage of:

- Convenient online submission

- Thorough peer review

- No space constraints or color figure charges

- Immediate publication on acceptance

- Inclusion in PubMed, CAS, Scopus and Google Scholar

- Research which is freely available for redistribution

Submit your manuscript at www.biomedcentral.com/submit
() Biomed Central

\section{Biomed Central}

(c) 2011 Heydarchi et al; licensee BioMed Central Ltd. This is an open access article distributed under the terms of the Creative Commons Attribution License (http://creativecommons.org/licenses/by/2.0), which permits unrestricted use, distribution, and reproduction in any medium, provided the original work is properly cited. 